\title{
American Freshman Survey Results
}

\section{Linda J. Sax}

Linda J. Sax is associate director, Higher Education Research Institute, University of California at Los Angeles. Address: Moore Hall, University of California at Los Angeles, Los Angeles, CA 90024.

$\mathrm{I}^{\mathrm{n}}$ n January, results of the 30th annual national survey of college freshmen were released by the Higher Education Research Institute at the University of California at Los Angeles. This study, initiated in fall 1966, is a project of the Cooperative Institutional Research Program, a continuing longitudinal study of the American higher education system sponsored by the American Council on Education and University of California at Los Angeles.

The 1995 national survey involved questionnaires completed by 323,791 freshmen entering a national sample of 641 two- and four-year colleges and universities. Of these, 240,082 questionnaires-from 473 institutions judged to have surveyed the most representative samples of entering freshmen-were used to compute national norms to represent the nation's total population of approximately 1.52 million first-time freshmen. Following is a summary of the 1995 results, along with highlights of major trends in the survey since 1966.

\section{The 1995 national survey involved questionnaires completed by 323,791 freshmen entering a national sample of 641 two- and four-year colleges and universities.}

Declining Political Interest and Engagement

College freshmen feel increasingly disconnected from politics. Students' commitment to "keeping up to date with political affairs" as an important life goal dropped for the third straight year, to an all-time low of 29 percent, compared with a high of 58 percent in 1966 . The percent who discuss politics frequently also reached an all-time low of 15 percent, down from a high of 30 percent in 1968. Further, the percentage of students who believe that "an individual can do little to change society" reached a ten-year high, at 34 percent.

\section{Freshman Attitudes}

While an increasing number of freshmen label their political views as "middle of the road" (54 percent), attitudes about specific political and social issues span the ideological spectrum. On the conservative side, trends indicate de- clining support for sexual and reproductive freedom. Despite steadily rising support for abortion rights during the late 1980s, support for keeping abortion legal declined for the third straight year, to 58 percent—compared to a high of 65 percent, in 1990. At the same time, support has reached an all-time low for the notion that "If two people like each other, it's all right for them to have sex even if they've known each other for a very short time," decreasing from 52 percent in 1987, to 43 percent in 1995.

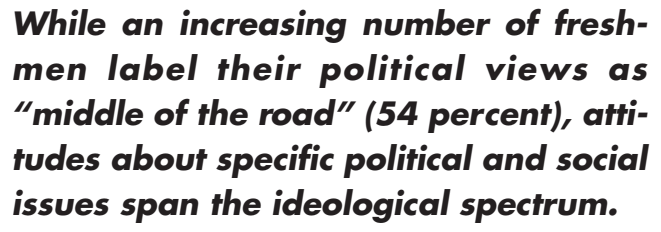

On some issues, there has been movement in the liberal direction. The belief that homosexual relationships should be prohibited has declined from a high of 53 percent in 1987 to an all-time low of 31 percent. Support for legalizing marijuana has reached a 15 -year high of 34 percent, up from 17 percent in 1989. Support for mandatory employee drug testing has dropped from 81 percent in 1994 to 77 percent in 1995. Finally, the belief that people should not obey laws that violate their personal values has reached an all-time high, at 38 percent-compared with 32 percent, in 1975.

\section{Religious Interest}

The 1995 survey indicates that more freshmen than ever have "no religious preference"-15 percent, compared with a low of 8 percent in 1978. Further, more freshmen than ever (19 percent) say they never attended religious services during the past year, compared with 9 percent in 1968.

\section{Academic Disengagement}

The survey also indicates that students are increasingly disengaged from the academic experience. The 1995 survey shows more students than ever (34 percent) reporting being frequently bored in class. During their senior year in high school, students are spending less time studying or doing homework, less time talking with teachers outside of class, and less time in student clubs or groups. Instead, they are spending more of their time socializing and working for pay. 


\section{Gender Differences in Time Allocation}

The 1995 survey highlights interesting gender differences in how students spend their time. Men are more likely than women to spend six or more hours per week on exercise/sports (62 percent, compared with 41 percent among women), partying (36 percent, compared with 26 percent among women), and watching television (36 percent, compared with 25 percent among women). Men are also far more likely than women to spend time playing video games (37 percent spend one or more hours per week, compared with 7 percent among women). In fact, 1 out of 11 male college freshmen spend six or more hours per week playing video games, compared with only 1 out of 100 among women freshmen.

\section{The 1995 survey shows more students than ever (34 percent) reporting being frequently bored in class.}

Women, on the other hand, are more likely than men to spend their time studying or doing homework (41 percent report six or more hours per week, compared with 28 percent among men). Women are also more likely than men to spend one to five hours per week on household/ child care (53 percent, compared with 38 percent among men), participating in student clubs/groups (45 percent, compared with 32 percent among men), reading for pleasure (43 percent, compared with 34 percent among men), performing volunteer work (33 percent, compared with 25 percent among men), and talking with teachers outside of class (45 percent, compared with 39 percent among men). Further, women are twice as likely as men to report feeling frequently "overwhelmed" by all they have to do (33 percent, compared with 17 percent among men).

For additional information on the freshman survey or to order the 1995 results, please write or call: Higher Education Research Institute, UCLA, Graduate School of Education \& Information Studies, 3005 Moore Hall/Mailbox 951521, Los Angeles, CA 90095-1521. Phone: 310/8251925, Fax: 310/206-2228; e-mail: HERI@gse.ucla.edu

\section{The Deregulation of Higher Education in Taiwan}

\section{Ching-Hwa Tsai}

Ching-Hwa Tsai, Ed.D. is associate professor and chair, Department of Elementary Education, National Pingtung Teachers College, Taiwan. Email address: tsai@pintu.npttc.edu.tw

$\mathrm{T}$ aiwan's higher education system has entered a dramatic stage of increased activity during the last several years-beginning in 1988, when martial law was lifted. The number of four-year higher education institutions increased 49 percent, from 39 (in 1988) to 58 (in 1994), while the number of students increased roughly by 52 percent, from 224,820 to 341,320 . Before 1994, when the University Law (regulating only the four-year degree-granting colleges) was revised, the cabinet-level Ministry of Education dominated almost every aspect of higher education institutions - public and private-including the tuition each campus charged, the courses offered, the students recruited (through a ministry-organized joint entrance exam board), and the appointment of each college's president.

\section{The revised University Law reduced the power of the Ministry of Education over higher education institutions, and cam- pus operations have become more flex- ible.}

\section{Initiative for Deregulation}

In 1988, as a friendly gesture to the country's main opposition party (the Democratic Progress Party) and to show its determination to implement real democracy, the ruling Kuomingtang (the National Party) declared an end to the 40-year long martial law. This encouraged many college professors to call for more academic freedom. As a result, the ministry agreed to revise the University Law, which regulated a great deal of college operations. During the period between 1990 and 1994, more than five versions of bills to revise the University Law were sent to the Legislative Yuan, the country's highest legislative body, and received enormous attention from the public. A revised University Law was eventually passed in 1994. The revised University Law reduced the power of the Ministry of Education over higher education institutions, and campus operations have become more flexible. 